\title{
THEORETICAL FOUNDATIONS OF THE CREDIT MECHANISM OF MEETING CONSUMER NEEDS OF THE POPULATION
}

\author{
Violetta Kharabara', Roman Greshko²
}

\begin{abstract}
Purpose. A significant role in ensuring the socio-economic development of the state, increasing the economic activity and purchasing power of the population is played by the credit mechanism of meeting the consumer needs of the population. However, the effects of crisis phenomena in the state economy have created high credit risks, which negatively affected the dynamics of consumer lending in Ukraine. Method. Thus, the purpose of this article is to study the financing of the real sector of the economy and increase its capital due to the effective functioning of the credit mechanism of meeting the consumer needs of the population. Research results. The theoretical approaches of scientists to the essence, elements and components of the credit mechanism of meeting the consumer needs of the population, external and internal factors influencing its efficiency, such as the ability of the borrower to return the credit, availability of credit, interest rate, as well as maturity and repayment terms are investigated in the paper. Also, the study analyzed legislative and regulatory acts on the development of credit relations and the banking system in Ukraine. The problems of organization of credit activity of banks, formation of effective credit policy, choice of effective methods, types of lending are considered. Particular attention is paid to the most common type of crediting of consumer needs with credit cards in the modern way. Value/originality. As a result, the paper proposes to consider the essence of the credit mechanism of meeting the consumer needs of the population as a set of forms and tools for influencing the system of credit relations between the subjects of lending to the consumer needs in order to provide the necessary volumes of consumer credit. In turn, as a result of using the method of comparative analysis, the list of consumer lending facilities is systematized in the work, the classification of credits for consumer needs of the population is improved, and the author's vision of the main components of the credit mechanism of meeting the consumer needs of the population is characterized.
\end{abstract}

Key words: credit relations, consumer needs, credit policy, banks, Ukraine.

JEL Classification: E51, G21

\section{Introduction}

At the current stage of Ukraine's economic development, an important place in the search for ways of economic growth is occupied by the task of forming effective credit relations in the process of development of the consumer market of the state. A significant role in ensuring the socio-economic development of the country, raising the living standard of the population is played by consumer lending. In the context of the effects of crisis phenomena in the state's economy, the problem of pulling people's savings to finance the development of the real sector of the Ukrainian economy has become significantly aggravated. The provision for consumer needs of the population is characterized by an increase in interest rates, initial payments and commissions on credit proposals, a decrease in the value of mortgaged property, and an increase in requirements for borrowers in the near-term stop of the lending market. In addition, the decline in economic activity and further deterioration in purchasing power of the population have a negative impact on the dynamics of consumer lending. Taking into account high credit risks, the recovery in the growth of lending to the consumer needs of the population is slow and mainly short-term.

In turn, the acceleration of international capital flows leads to increased competition in the

\footnotetext{
Corresponding author:

${ }^{1}$ Yuriy Fedkovych Chernivtsi National University, Ukraine.

E-mail: v.kharabara@chnu.edu.ua

ORCID: https://orcid.org/0000-0002-8555-6440

${ }^{2}$ Yuriy Fedkovych Chernivtsi National University, Ukraine.

E-mail: r.greshko@chnu.edu.ua

ORCID: https://orcid.org/0000-0003-3054-356X
} 
consumer lending market due to the strengthening of market positions of non-bank organizations, brokerage, mortgage companies, which requires new approaches to meet the consumer needs of the population. The sphere of consumer lending is directly related to the needs for the development of national production, serving the interests of households and mediating the connections between the state, financial and credit institutions, commodity producers and the population.

Under these conditions, methods and instruments for lending for the consumer needs, sources of credit repayment, the peculiarities of the formation of the cost of credits for consumer needs of the population and the socioeconomic efficiency of the credit mechanism of meeting the consumer needs of the population require in-depth scientific study.

\section{Research results}

The problem of crediting the consumer needs of the population is constantly enriched with new scientific developments, but the theoretical integrity and practical effectiveness of its development is insufficient, as there is a continuing controversy among scientists and practitioners about understanding the essence of the credit mechanism of meeting the consumer needs, the economic nature of this category and its main components. In this regard, it is important to develop a holistic paradigm of understanding the essence and basic components of meeting the consumer needs of the population, which would integrate all their features.

Credit is a form of cash flow that is provided in the form of a credit. Credit provides a transformation of monetary capital into a credit and expresses the relationship between commercial banks and borrowers. Solving the problems of the formation of a market environment and economic growth depends on the efficiency of the credit mechanism of banks and the banking system as a whole, which is explained not only by the increase in their role in the development of the economy, but also the opportunity to react quickly and effectively to newly introduced management mechanisms.

In their studies, such scholars as Kirichenko O.; Moroz A., Savluk M., Pukhovkina M.; Savluk M., Moroz A., Lazepko I.; Vitlins V. Pernarovsky O., Nakonechny Ya., Velikoivanenko G. consider only certain elements of the credit mechanism. Thus, credit policy is defined as a strategy and tactics of raising funds and directing them to lending to customer needs based on the principles of return, urgency, differentiation, security, and payment.

Important is the opinion of these scholars that the credit policy allows them to plan, regulate, control, rationally organize the relationship between the commercial bank and its clients in relation to the reverse flow of funds.

In turn, the authors of the article include to the components of the credit mechanism such elements, as: the classification of bank credits, the principles of bank lending, methods of lending and the form of credit accounts, the creditworthiness of borrowers and methods for its determination, the forms and types of security for the repayment of bank credits, principles and requirements for the conclusion of bank credit agreements with borrowers, the basic principles and legal aspects of lending to the market economy and the population. Among the principles, the return, urgency, differentiation, security and pay are distinguished. Consequently, the principles of bank lending are the basis of the credit mechanism, since they reflect the essence and content of the credit and the requirements of objective economic laws in the field of lending.

The issue of lending methods is considered in a number of works by the authors such as Liutyi I., Kryklii A., Mischenko V., Naumenkova S., Versal N.; Moroz A., Savluk M., Pukhovkina M.; Savluk M., Moroz A., Lazepko I., where the method of lending is defined as a method of granting and repaying a credit in accordance with the principles of lending. Thus, lending methods determine the type of credit, ways of regulating possible credit debt, the form and procedure for monitoring the purposeful use of borrowed funds and their timely return.

For comparison, in the practice of the Ukrainian banks (PJSC JSCB "ARCADA", PJSC "VTB BANK", PJSCCB "PRAVEX-BANK", PJSC "UKRSOTSBANK", JSC "Raiffeisen Bank Aval", JSC "Ukreximbank") two methods of lending are used. The essence of the first method is an individualized approach to granting a credit, that is, a credit is provided to meet a certain target need for funds. This method is used to provide credits on specific terms, which are determined in advance. According to the second method of lending, credits are provided within the limits set by the bank in advance of a certain borrower, which is used by him or her as necessary, by payment of payment documents received during a certain period, that is, 
in this case, the bank opens the borrower's credit line. This form of provision is used for clients with a stable financial standing.

The effectiveness of the credit mechanism of commercial banks depends on two groups of factors - external and internal. Authors such as Liutyi I., Kryklii A., Mischenko V., Naumenkova S., Versal N., Liubkina O., Rozhko O.; Onishchenko V.; Pernarovskyi O.; Vitsinskyi V., Pernarovskyi O., Nakonechnyi Ya., Velikoivanenko G. underline the impossibility of the existence of a single, sustainable credit mechanism for all commercial banks, since each bank defines its own credit policy, taking into account all the set of internal and external risks that affect the effectiveness of its activities, and the attitude of the bank's management to risk. It is debatable that in this case, the concept of credit mechanism and credit policy of a commercial bank are identified, and, in fact, credit policy is defined as a set of measures aimed at minimizing internal and external credit risks.

According to Vitlinskyi V., credit policy is the basis of the risk strategy in the bank and can be aggressive and traditional. The basis of the credit policy is the bank's strategy is aimed at increasing its capital or increasing current income, or a mixed strategy. Consequently, credit policy in the narrow sense is a system of bank facilities in the area of lending its clients, which the bank carries out to implement its general strategy for a certain period of time.

The results of scientific research by the team of authors Moroz A., Savluk M., Pukhovkina M. indicate that the credit policy of commercial banks has its own internal structure. Summarizing the results of the study, we will present the main elements of the credit policy: a strategy for the directions of the credit process; tactics of lending organization; control and monitoring the implementation of the chosen strategy and tactics.

The efficiency of the credit mechanism of meeting the consumer needs of the population is significantly dependent on the intensity of competition in the banking sector, which differs in the development of forms, accompanied by the development of information technology and communications, which leads to the expansion of the territorial scope of banks, the spectrum of banking products and services, increases the diversification of the banking industry. Therefore, the credit mechanism of meeting the consumer needs of the population contains, as a component, a credit policy, but, in addition, should be supplemented by: a detailed classification of credits for consumer needs of the population and facilities for lending for the consumer needs of the population; definition of forms, methods, tools and directions of crediting of consumer needs of the population; elements of macroeconomic modeling in relation to the formation of the value of credits for consumer needs of the population; definition of conditions, forms and methods of cooperation of crediting subjects of consumer needs of the population with market institutions that influence the efficiency of credit relations.

The authors of the study agree with Galchinsky A. that the activities of financial and credit institutions should be subordinated to the main macroeconomic task, namely: to balance economic development, to ensure optimal employment and to curb inflation. The activities of commercial banks should promote the introduction of economic ideology to stimulate solvent demand and supply of goods.

Issues of organizing credit activities of commercial banks are reflected in the writings of foreign authors: Ansoff, Barltrop \& McNaughton, Frost, Edwards, Karloff, Kaufman, Rose \& Hudgins, Sinkey, Woelfel. In the definitions given by foreign economists, the effectiveness of the credit mechanism is determined by the focus on increasing consumer demand, using a bank of the most profitable markets for the sale of banking products, taking into account the real needs of borrowers.

The effectiveness of a bank's lending activity depends on the optimally created commodity, price, communication and marketing policies of the bank, as stated in Dickson's work. The Bank focuses on specific functions of the bank in providing credit services, namely: studying and forecasting demand for banking products, issuing banking products, pricing, creating an image, expanding market shares.

In studies by researcher Romanenko L., there is a meaningful description of measures for the formation of consumer demand for credit products, namely: concentration of efforts of the bank to meet the needs of the client, focusing on the longterm result of the focus on achieving the final result.

Thus, in the above definitions, the focus is on the commercial aspect of an effective lending mechanism, insufficient attention to strategic performance of the bank; the emphasis is on achieving the optimal end result under certain 
conditions, however, in our opinion, the effectiveness of the implementation of the credit mechanism is determined, first of all, by the socioeconomic efficiency of lending activities.

It should be noted that the effectiveness of the credit mechanism is determined by the priorities of selecting the target segment of clients; the competence of the bank's management, professional training and experience of the personnel, persons involved in the selection of specific credit applications and forms the terms of credit agreements. Thus, the credit mechanism, in a strategic way, includes the priorities, principles and objectives of a separate bank in the lending market, tactically - the toolkit used to implement goals for the implementation of credit agreements, the rules for their implementation, the rules of the organization of the credit process.

The credit takes specific forms that enable the existence of the lending process. The credit form reflects the external manifestation and organization of credit relations. In a market economy, there are different forms of credit, which differ by the subject and object of the credit, the source of payment of interest, the specific content of the credit agreement. Forms of credit are constantly evolving, accordingly their place in the structure of economic relations changes.

The question of the forms and types of credit in economics is debatable. Differences in the approaches of economists depend on understanding the criteria, principles and classifications of forms of credit. The authors of the article share the opinion of researcher Lagutin V. concerning the following forms of credit: commercial credit; bank credit; state credit; consumer credit; mortgage credit; leasing credit; international credit.

Credit relations mediate the functioning and development of both production and exchange, and the sphere of final consumption. In this area there is a specific form of credit: a credit for consumer needs, designed to meet the consumer needs of individuals and households. An essential feature of a credit for consumer needs - end-user financing. The peculiarity of a credit for consumer needs is that the main guarantee of its provision and return is the constant cash income of a physical person the borrower. The population is able to consume goods and services at the time of payment of their full value. Thus, the development of lending to consumer needs contributes to raising the standard of living of the population. In macroeconomic terms, lending to consumer needs of the population increases the total solvent demand for consumer goods and services, which, in turn, stimulates the expansion of their production volumes.

According to the authors of the study, the factors that determine the effectiveness of lending to consumer needs are: the ability of the borrower to repay the credit; availability of credit; interest rate; maturity and repayment terms.

According to Pernarivsky O., the subjects of lending, consumer needs of the population are commercial banks, credit unions, mutual funds, credit cooperatives, credit exchanges, trade organizations, pawnshops, rental offices. The specifics of the final consumption sphere require, in the context of considering consumer financing lending, to identify trading organizations that carry out intermediary activities for the purchase of goods and services. Consumer credit is a form of cooperation of a trade organization with a financial and credit institution to meet the current demand of the population. In this case, the trade organization must find the optimal combination of direct sales of goods for money and sales in installments.

The object of lending to the consumer's needs of the population is the costs associated with satisfying the needs of the population, namely: the cost of meeting the needs of the current nature (the acquisition of goods in personal property); expenses for meeting capital and investment needs (construction, acquisition and maintenance of real estate). The proposed classification of lending facilities for consumer needs is shown in Figure 1.

Historically, the first form of credit for consumer needs was the so-called "tali trade" - trade in installments, which began to develop in Western Europe back in the 18th century. Traveling traders ("talimen") from time to time (for example, on a monthly basis) delivered goods in certain areas and sold to certain households, agreeing to a partial regular payment, with the delay of the final payment for a certain period (until their next arrival).

Credits for consumer needs include an extremely wide range of credit types. In the conceptual plan they distinguish commodity and money credits for consumer needs. Commodity credit for consumer needs is associated with the sale of durable goods in credit (with installment payment). Cash credit for consumer needs is the provision by financial and credit institutions of credits to individuals to meet consumer needs. Unlike the production credit, according to scientists, Savchuk V., Mazurko P., 


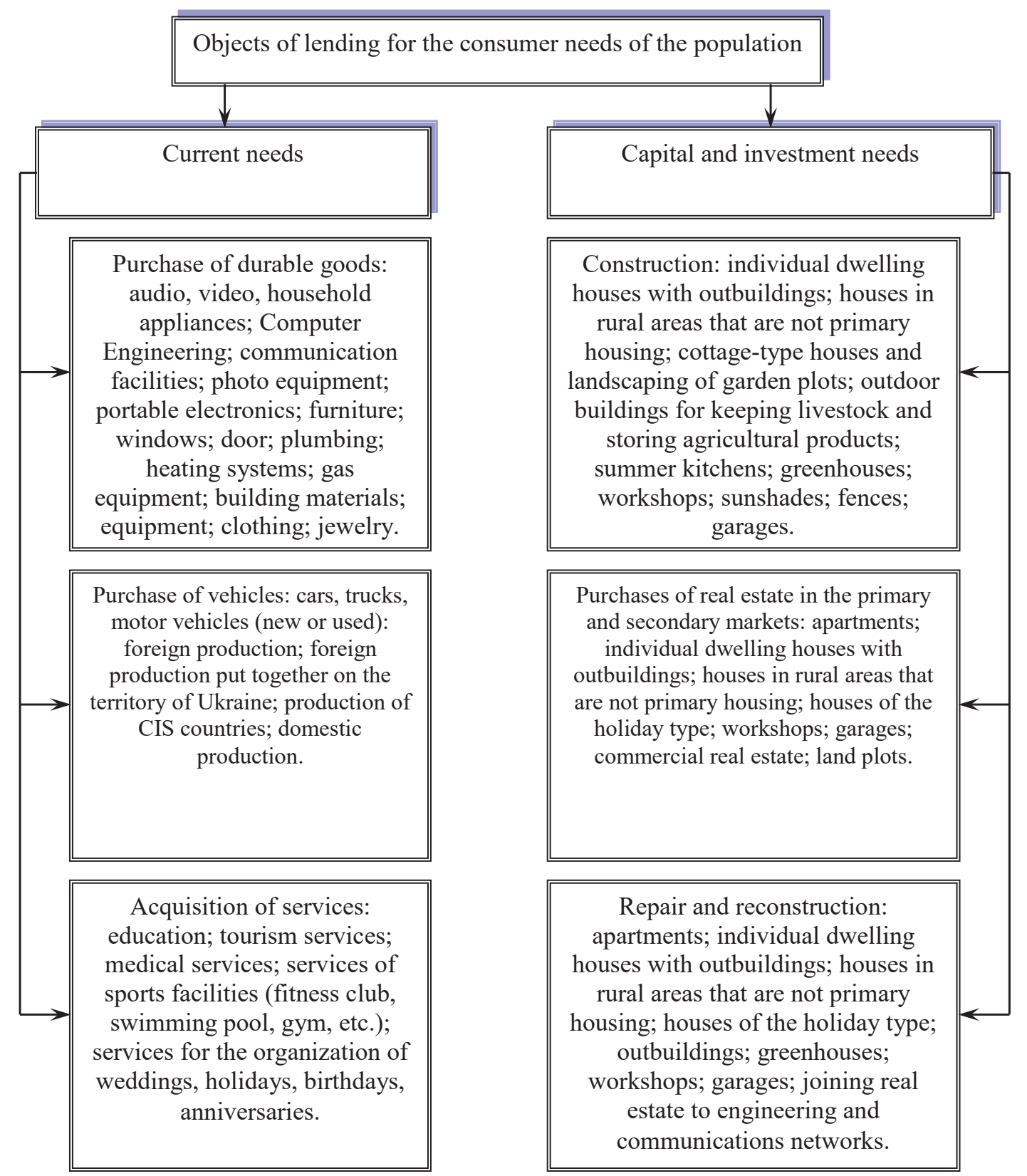

Figure 1. Classification of objects of crediting the consumer needs of the population

Source: was compiled by the authors on the basis of the results of lending of Ukrainian banks

Panchuk A., used to create a new value, the use of credit for consumer needs stimulates the growth of the value of the labor force proposed on the market.

The practice of crediting the consumer needs by domestic financial and credit institutions allowed the authors of this study to identify the following lending objects: the acquisition of real estate (mortgage credits); purchase of motor vehicles; purchase of durable goods; payment for services (training, treatment, tourism); receiving cash for other urgent current needs (see Figure 1).
The list of domestic and foreign manufactured goods recommended for sale by installments is tele-radio equipment, electrical household goods, sewing machines, musical instruments, cinema equipment, furniture, goods for newborn children, garden houses, standard houses with complete sets of details, building materials, clothing, footwear, carpets, crystal items, porcelain, earthenware, fur products, vehicles, personal computers, etc.

The sale of goods by installments is carried out on the basis of an agreement on the sale and purchase of goods in installments, which is concluded in 
a definite form between a business entity and an individual (buyer), according to which an entity undertakes to transfer the specified goods, and the buyer to make calculations for the good in terms and in the amounts stipulated by the agreement. Necessary, important and profitable is the sale of expensive goods in installments, both for business entities, which have many problems with the sale of products, and for consumers, since it makes the majority of goods available.

Depending on the target nature (appointment), different types of cash credits are used, namely: investment credits; credits for the development of individual farms; credits for the purchase of consumer goods or payment for services; targeted credits to individual social groups (young families, students); credits for non-target consumer needs.

According to Kravchuk K. and Turpak A., investment credits are credits for the construction and renovation of housing, the construction of garden houses, landscaping garden plots. This type of consumer credit is long-term. Long-term consumer investment credits are provided by commercial banks on mortgage - apartments, houses, cottages, land plots, garages. Provision of building consumer credits is often carried out by the bank by opening a credit line, with the credit being provided to the client by parts that correspond to the cost of completed stages of construction and installation work.

Credits for the purchase of consumer goods or payment services include the purchase of expensive goods and services for long-term use, namely: cars, household appliances, electrical engineering, furniture, medical services, recreation, etc. Such a credit has a social orientation, therefore it should be accessible to the necessary volumes for the majority of citizens. Target credits to individual social groups (young families, students, etc.) are used within the framework of national programs of social protection of the most vulnerable sectors of the population. They are provided on preferential terms: at a low interest rate, under simplified terms of execution.

Credits for non-target consumer needs are credits, the need for which arises due to special circumstances of unforeseen nature in the life of the population.

The feature of this type of credit for consumer needs is that it is provided in cash in an amount that depends on the borrower's income and without specifying the purposes of its use. Interest for using this credit is differentiated depending on the maturity of the credit. Unsolicited cash credits are also provided by pawnshops on property pledges, mutual assistance pays, and separate economic organizations.

According to the subjects of credit relations - in terms of the creditor - credits for consumer needs are divided into bank and non-bank; in terms of the borrower - credits provided to all segments of the population, different social groups, different age groups; by way of provision - direct credits provided directly to borrowers, and indirect, provided through intermediaries (trade organizations, pawnshops, rental offices); by the degree of coverage of the credit of the cost of consumer goods and services - credits for full value and for partial payment of goods (services).

One kind of credit for consumer needs is a credit provided by pawnshops. Pawnbrokers are credit institutions that borrow money on a pledge of movable property. For the first time, pawnbrokers were founded in the 15th century by moneylenders who came from Lombardy. In Ukraine, the network of pawnbrokers has been widely developed on municipal (city) and joint-stock basis in the late 19 th - early 20 th century.

The main task of the activity of the pawnshops is to provide credits to the population on the pledge of personal and household goods, as well as the preservation of these items for a small fee. As a rule, property is taken as collateral, which can be realized quickly. In this case, the mortgage provides the repayment of the credit. The insurance of the acquired property takes place at the expense of the mortgagor.

Pawns give a credit at an amount that is less than the value of collateral. As a rule, precious metals and stones, pearls, gold watches, for which the size of the credit may reach up to $90 \%$ of the value estimate, are most "valued" as collateral. The borrower retains the ownership of the property entrusted to the pawnshops. In the case of nonrepayment within the established term of the credit, as well as the evasion of the person who has laid things in the pawnshop, from their receipt, the right of ownership passes to the pawnshop, which transfers the property for sale (realization). From the proceeds, the pawnshop holds the amount of debt, accrued interest, remuneration, insurance costs of the pledged property and its sale.

Consumer credits are also provided by nonbanking institutions such as credit unions, mutual assistance funds, and credit cooperatives, which are voluntary organizations based on personal savings for mutual lending. These lending institutions 
are not intended to receive profits, therefore they provide credits without interest or at minimum interest. Credit unions work with those strata of the population who, for economic reasons, cannot get a credit in a bank. Such lending institutions meet the needs of their members in small credits for consumer and production needs.

The specific component of the credit mechanism of meeting the consumer needs is the rolled items. For registration of a rental agreement, the client submits a passport and a certificate from the place of work or training. The contract stipulates the term rental and the monthly tariff. Payment notes are marked and issued in duplicate. For each day of delayed payment, a penalty of $1 \%$ of the amount of monthly tariff is charged. Repairs of rental facilities are carried out at the expense of a rolling point, if the damage is not the result of improper exploitation of the property by the recipient.

The main share of credits for consumer needs of the population falls on banks. In Ukraine, one of the types of cash bank credits for consumer needs is the checking credit and bank credit cards. Checking credit is a type of credit for consumer needs, which provides a credit through the opening of a checking account. In banking practice, two main types of check credit are used: lending from an overdraft account (with a negative balance on the current account) and lending based on the use of a special checking account and special bank checks.

In modern terms, the most widespread is the crediting of consumer needs by means of a credit card. The main advantage of a credit card is the convenience of practical use. A credit card is a registered (with the owner's identifier) cash payment-settlement bank document that is used to provide a credit for consumer needs. Today, in developed world countries, credit cards come in first place as a means of calculating consumption. Credit cards in the monetary sphere replaced cash and checks: payments for goods and services are carried out by the borrower at the expense of their credit card. The use of credit cards greatly facilitates the provision of credit for consumer needs, but increases the risk of abuse and fraud.

The use of credit cards organizes economic relations, in the process of lending to consumer needs, between the three entities: a commercial bank; cardholder (borrower); trading organization. Between a commercial bank and a trade organization, an agreement is concluded on the use of this bank's credit cards when purchasing goods. The trading organization must give its official consent to accept the cards of this bank when calculating for the goods. For a commercial organization, a credit card is a guarantee of opening for a buyer of a credit in a bank.

On a periodic basis (or immediately), trade organizations transfer to the bank bills for goods sold to credit card holders. The bank pays these bills by transferring a certain amount of funds to the current account of the trading organization. Gradually the lending limit is exhausted and if the cardholder does not repay his or her obligations to the bank, the card loses its validity. Credit card holders are constantly receiving information on the balance of the credit limit on it and, accordingly, on the need to extend the credit. Thus, the stages of the process of crediting consumer needs through credit cards are as follows: the issuance of a credit card by a bank to the client-borrower; purchase by the borrower of goods through credit card calculation; transfer of bills for the purchased goods to the bank by a trade organization; transfer of funds from the bank to the current account of a trading organization; return of the borrower's funds to the bank.

The bank receives interest on the credit granted to holders of cards within the credit limit. The bank regulates the size of the credit limit on cards and periodically restores the cards itself, which allows it to overestimate the creditworthiness of cardholders. As a rule, only leading commercial banks are able to issue their own credit cards, because in order to provide profit, the distribution system of cards should be large enough. The main costs associated with the use of credit cards for banks are the costs of their release to the market and the search for a commercial network that would have agreed to accept them as a means of payment. It is clear that the issue of their own credit cards is a rather expensive banking transaction. Therefore, in practice, banks use national (even worldwide) credit card systems (VISA, MasterCard, American Express, etc.). It should be noted that credit cards for consumer needs are issued not only by banks but also by airlines, railways, hotels, telephone companies, and trade organizations.

According to the authors of the study, a credit for consumer needs of the population should be understood as a credit, aimed at satisfying the personal needs of individuals, that is, serving the sphere of personal consumption. The proposed classification of credits for consumer needs is presented in Figure 2. 


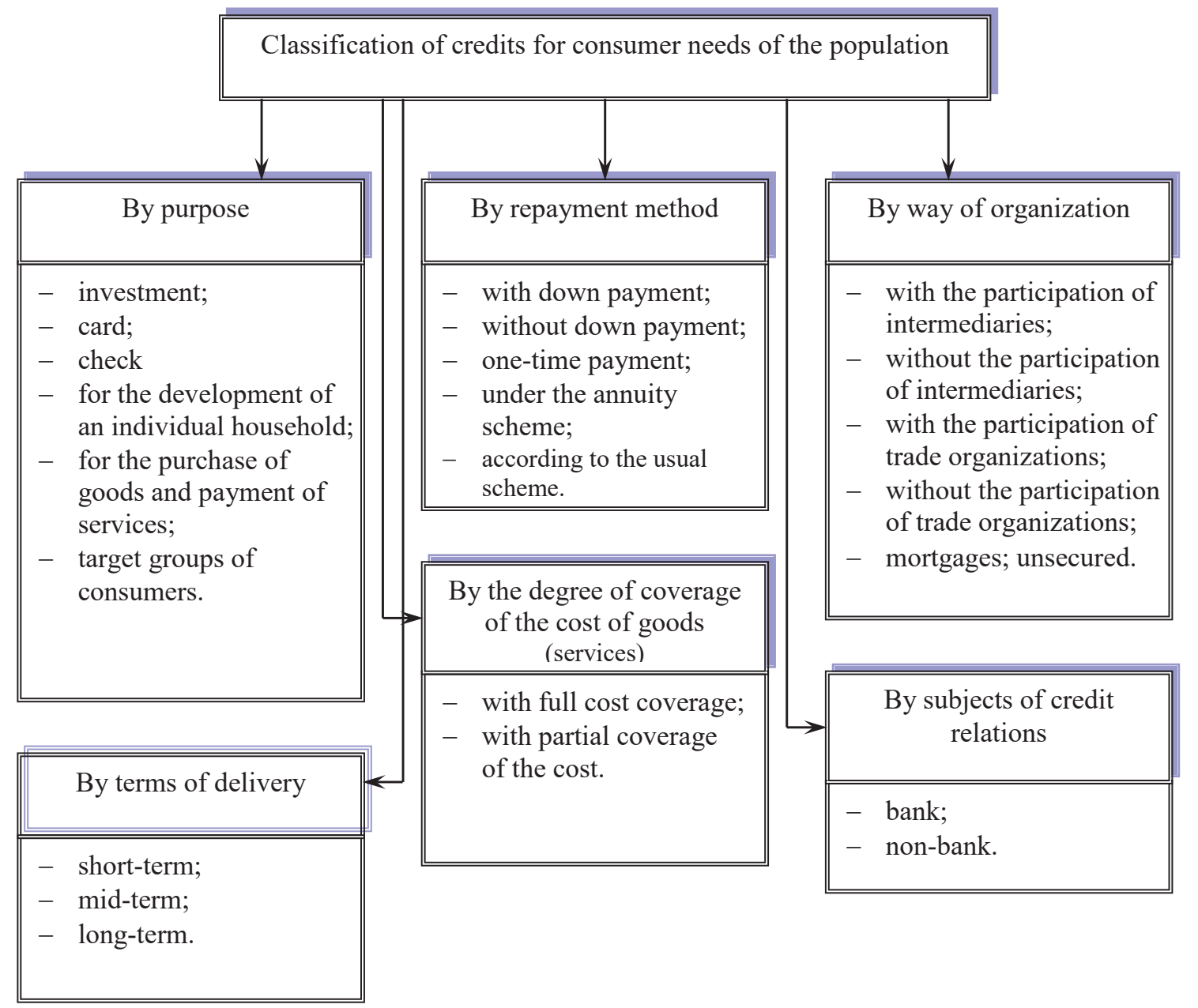

Figure 2. Classification of credits for consumer needs of the population

Source: compiled by authors

In turn, the authors of the study propose to determine the credit mechanism of meeting consumer needs of the population as a set of forms, methods and tools for forming credit relations between the subjects of consumer credit financing for the development of the sphere of final consumption and the financial services market of Ukraine, with the participation of market institutions that affect the efficiency of credit relations. The main components of the credit mechanism of meeting the consumer needs are presented in Figure 3.

The basis of the credit mechanism of meeting the needs of existing and potential customers is the credit policy of lending entities, which determines the priorities of the development of credit relations through the offer of a wide range of credit products and services. The credit policy contains the objectives, principles and conditions for granting credits to different categories of borrowers, priority areas of credit activity, allocation of powers, limits on credits to one borrower, requirements for the provision and repayment of a credit, the procedure for granting credits to employees and founders of the bank, a set of quality control measures for the credit portfolio.

The essence of credit policy is determined by the peculiarities of lending to consumer needs, namely: - consumer credit refers to the relationship between the creditor and the borrower, whose purpose is to finance end-use consumption, in contrast to credits provided to business entities for production purposes or for the acquisition of assets generating the movement of value;

- users of consumer credit are mainly individuals;

- consumer credit is a means of meeting the consumer needs of the population, that is, personal, individual needs. Lending to the population, on the one hand, increases their solvent demand, living standards in general, and, on the other hand, 


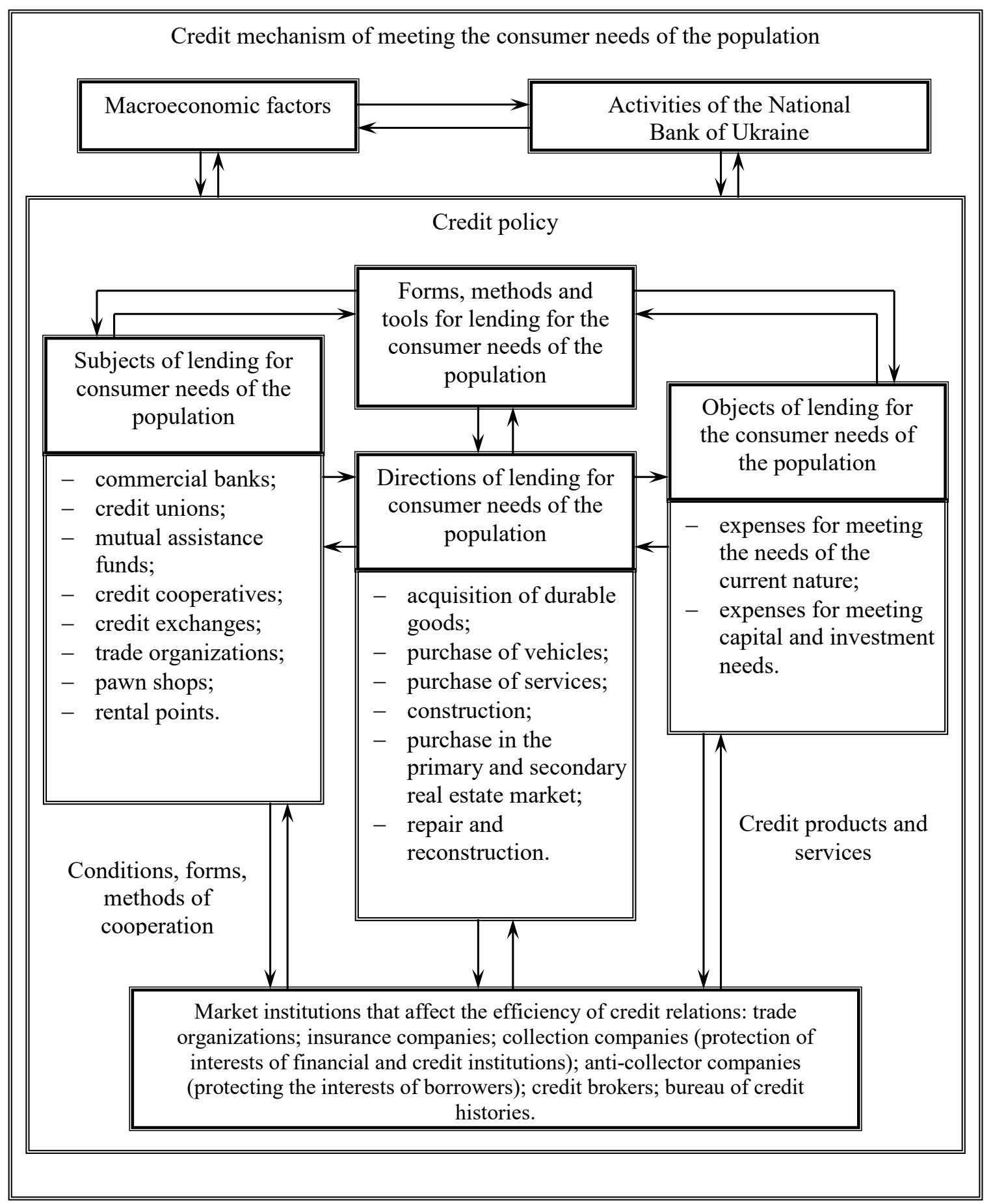

Figure 3. Components of the credit mechanism of meeting the consumer needs of the population.

Source: compiled by authors

accelerates the sale of inventories and services, contributes to the creation of fixed assets of production enterprises;

- all types of credit for consumer needs are social in nature, as they contribute to solving social problems: raising the standard of living of the population (especially low and middle income), the adoption of the principles of social justice. The above has a manifestation in preferential terms of lending and development of loyalty programs.

Credit relations between the subjects of consumer lending mediates the development of the final consumption, which necessitates the cooperation of trade organizations and financial and credit 
institutions. An additional condition for consumer lending is the life insurance of a borrower, which requires the involvement of insurance companies in cooperation.

The efficiency of the functioning of the credit mechanism for providing consumer needs is significantly influenced by macroeconomic factors that shape the solvent demand of the population, as well as trends in the banking system in terms of volume dynamics, transformation of credit portfolios of banks, and dynamics of problem debt volume. At low level of solvent demand of the population at considerable volumes of the given credits the volume of problem debts of creditors, which requires attraction of collecting companies in the sphere of credit relations, significantly increases. In addition, according to the authors, the reduction of the volume of problem debts in the credit portfolios of financial institutions is facilitated by cooperation with credit brokers and a bureau of credit histories.

\section{Conclusions}

It can be argued that solving the problems of the formation of a market environment and economic growth depends on the efficiency of the credit mechanism of commercial banks and the banking system as a whole, which is explained not only by the increase in their role in economic development, but also by the opportunity to respond quickly and effectively to newly introduced management mechanisms. The basis of an efficiently functioning credit facility is the planning of credit activities, justification of their expediency taking into account the trends of economic development of the country and the banking system, in particular.

In this paper, the authors investigated the credit mechanism of meeting consumer needs by structuring the relationships between subjects and objects of lending to consumer needs, forms, methods and tools for the formation of credit relations in the conditions of the development of the consumer market, which allowed to obtain the following results of the study:

- with the help of comparative analysis, the authors improved the classification of credits for consumer needs of the population, which provides for their division by purpose, terms of provision, repayment method, the degree of coverage of the cost of goods (services), the way of organizing credit relations, subjects of credit relations, while a credit for consumer needs of the population means a credit, which is aimed at satisfying the personal needs of individuals and serving the sphere of personal consumption;

- the work proposes its own definition of the credit mechanism of meeting consumer needs of the population as a set of forms and tools for influencing the system of credit relations between the subjects of lending to the consumer needs of the population in order to provide the necessary volumes of consumer credit;

- the authors identify the main components of the credit mechanism for the provision of consumer needs, such as: the credit policy of consumer crediting entities, which is formed under the influence of macroeconomic factors and regulatory measures of the central bank of Ukraine; subjects and objects of lending; forms, methods, tools and directions of consumer lending; market institutions that affect the efficiency of credit relations.

Resolving the problems of effective functioning of the credit mechanism of meeting the consumer needs of the population remains relevant, concerning the coverage of new methods, conceptual approaches to the valuation of mortgaged property, risk insurance for nonrepayment of credit and determination of the value of credits for consumer needs of the population. These problems require additional study and will be the subject of further scientific research by the authors.

\section{References:}

Ansoff, H. (2007). Strategic Management. UK: Palgrave Macmillan, 251 p.

Barltrop, C. J., \& McNaughton, D. (1992). Banking Institutions in Developing Markets: Interpreting financial statements. Washington, DS: World Bank. Retrieved from: http://documents.worldbank.org/ curated/pt/595921468762360904/pdf/multi-page.pdf

Bondarenko, N. V. (2014). Suchasnyi stan kredytuvannia komertsiinymy bankamy fizychnykh osib v Ukraini [The current state of lending to commercial banks of individuals in Ukraine]. Collection of scientific works of Uman National University of Horticulture, vol. 85, pp. 242-248.

Chaikovskyi, I. (2017). Analiz suchasnoho stanu ta perspektyvy rozvytku bankivskoho spozhyvchoho kredytuvannia v Ukraini [Analysis of the current state and prospects of development of bank consumer 
lending in Ukraine]. Publishing and Printing Center of Ternopil National Economic University "Economic Thought", vol. 27, no. 1, pp. 156-163. Retrieved from https://www.econa.org.ua/index.php/econa/ article/download/1278/pdf

Dickson, P. R. (1993). Marketing Management. Dryden Press, 621 p.

Frost, S. M. (2004). The Bank Analyst's Handbook: Money, Risk and Conjuring Tricks. Wiley, 552 p.

Edwards, B. (2004). Credit Management Handbook. Gower Publishing, Ltd., 561 p. Retrieved from: https://ru.scribd.com/document/335467871/Credit-Management-Handbook-pdf

Halchynskyi, A. (2006). Teoriia hroshei: navchalnyi posibnyk [Theory of money: educational manual]. Kyiv: Fundamentals, 415 p.

Karloff, B. (1989). Business Strategy. A Guide to Concepts and Models. UK: Palgrave Macmillan.

Kaufman, H. (2008). Marketing «one to one» et marketing bancaire. Banque, pp. 60-61.

Kravchuk, K., \& Turpak, A. (2008). Kryzy ne bude [There will be no crisis]. Kiev: Contracts, no. 33-34, pp. 10-11.

Kyrychenko, O. A., Hilenko, I. V., Rohol, S., Syrotian, S. V., \& Niemoi, O. (2002). Bankivskyi menedzhment [Banking Management]. Kiev: Knowledge Press, 438. Retrieved from: http://mmlib.net/knigi/ bankovskoj-menedzhment/kniga-7

Lahutin, V. D. (2002). Kredytuvannia: teoriia i praktyka [Lending: theory and practice]. Kiev: Knowledge, no. 3, $215 \mathrm{p}$.

Liutyi, I. O., Kryklii, A. S. Mishchenko, V. I., Naumenkova, S. V., \& Versal, N. I. (2008). Bankivska sprava [Banking]. Kiev: Kiev University, 392 p.

Liutyi, I. O., Versal, N. I., Liubkina, O. V., \& Rozhko, O. D. (2008). Hroshi ta kredyt: pidruchnyk [Money and credit: a textbook]. Kiev: Kiev University, 545 p.

Mayer, T., Duesenberry, J., \& Aliber, R. (2003). Money, banking, and the economy. N.Y.: W. W. Norton \& Company, Inc., 5.

Mishchenko, V., \& Shapoval, O. (2013). Suchasna praktyka spozhyvchoho kredytuvannia v Ukraini [Modern practice of consumer lending in Ukraine]. Bulletin of the National Bank of Ukraine, no. 11, pp.3-9. Retrieved from: http://nbuv.gov.ua/UJRN/Vnbu_2013_11_3

Moroz, A. M., Savluk, M. I., \& Pukhovkina, M. F. (2002). Bankivski operatsii [Bank operations]. Kyev: KNEU, no. 2, 476 p. Retrieved from: http://fingal.com.ua/content/view/153/83

Onyshchenko, V. O. (2003). Osnovy bankivskoi spravy [Basics of banking]. Poltava: PSTU, 157 p.

Osadchyi, Y. (2013). Suchasnyi stan ta problemy bankivskoho spozhyvchoho kredytuvannia v Ukraini [Current state and problems of bank consumer lending in Ukraine]. Securities Market of Ukraine, no. 11-12, pp. 97-102. Retrieved from: http://nbuv.gov.ua/UJRN/rcpu_2013_11-12_13

Peek, J., \& Rosengren, E. (2000). Implications of the Globalization of the Banking Sector: The Latin American Experience. New England Economic Review, September/October, pp. 45-62. Retrieved from: https://pdfs.semanticscholar.org/3c09/870ed66059fb28b381891fd40d9809aad0cf.pdf

Pernarivskyi, O. (2008). Stratehiia upravlinnia ryzykamy bankivskoho spozhyvchoho kredytuvannia [Banking consumer lending risk management strategy]. Bulletin of the National Bank of Ukraine, no. 5, pp. 40-43.

Romanenko, L. F. (2001). Bankivskyi marketynh: monohrafiia [Bank Marketing: Monograph]. Kyev: Publishing House "In Yure", 484 p.

Rose, P. S., \& Hudgins, S. C. (2013). Bank management \& financial services. NY: McGraw-Hill, no. 9, p. 740 p. Savchuk, V., Mazurok, P., \& Panchuk, A. (2007). Problemy optymizatsii upravlinnia spozhyvchym kredytuvanniam komertsiinykh bankiv [Problems of optimization of management of consumer lending of commercial banks]. Banking, no. 2, pp. 50-55.

Savluk, M. I., Moroz, A. M., \& Lazepko I. M. (2011). Hroshi ta kredyt [Money and credit]. Kyev: KNEU, no. 6, 589 p.

Sinkey, J. F. Jr. (1983). Commercial Bank Financial management. USA: Macmillan, 696 p.

Verkhovna Rada Ukrainy. (2016). Pro spozhyvche kredytuvannia [About consumer lending]. Retrieved from: http://zakon3.rada.gov.ua/laws/show/1734-19

Vitlinskyi, V. V., Pernarivskyi, O. V., Nakonechnyi, Y. S., \& Velykoivanenko, H. I. (2000). Kredytnyi ryzyk komertsiinoho banku [Credit risk of a commercial bank]. Kiev: Knowledge, $251 \mathrm{p}$.

Williams, B. (2002). The Defensive Expansion Approach to Multinational Banking. Financial Markets, Institutions and Instruments, vol. 11(2), pp. 127-203.

Woelfel, C. J. (2001). Encyclopedia of banking \& finance. Chicago: Probus Pub. Co. 